\title{
Corrigendum: Monitoring and mitigating isoflurane emissions during inhalational anesthesia of mice
}

Thomas E. Todd, DVM, Jennifer M. Morse, BS, RLATG, Todd J. Casagni, AS, RLATG, CVT \& Robert W. Engelman, DVM, PhD Lab Anim. (NY) 42, 371-379 (2013).

The machined facemask used for maintenance anesthesia in Condition 4 and shown in Figure 5 (left) was incorrectly identified in the Methods (page 375, first column, sixth sentence). The facemask is a product of VetEquip, Inc. (Pleasanton, CA).

\section{Erratum: Newsfronts}

Lab Anim. (NY) 43, 73 (2014).

In the section titled "Interfering with the progression of breast cancer," the correct bibliographic information for the Science Translational Medicine article cited is 6, 217ra2 (2014). 